\title{
Protein-losing enteropathy
}

\author{
A. S. TAVILL \\ From the Division of Metabolism, Clinical Research Centre, Northwick Park Hospital, Harrow, Middlesex
}

A large mass of evidence has been accumulated over the past 10 years which has conclusively demonstrated that the gastrointestinal tract plays a role in catabolism of plasma proteins (Wetterfors, 1965). An increased rate of catabolism resulting from excessive loss of plasma proteins into the gastrointestinal lumen is associated with hypoproteinaemia when the rate of synthesis is unable to compensate for this loss. This is the situation in a large number of gastrointestinal disorders (Citrin, Sterling, and Halsted, 1957; Schwartz and Thomsen, 1957; Gordon, 1959; Jeffries, Holman, and Sleisenger, 1962; Jarnum, 1963; Waldman, 1966; Waldmann, Wochner, and Strober, 1969).

Qualitative detection of serum proteins in the gastrointestinal secretions by electrophoretic and immunological techniques (Gullberg and Olhagen, 1959; Holman, Nickel, and Sleisenger, 1959; Barandun, Aebersold, Bianchi, Kluthe, Muralt, Poretti, and Riva, 1960) confirms that intact protein molecules pass across the gastrointestinal mucosa from plasma into lumen in health. However, they are then subjected to the normal digestive processes and subsequently reabsorbed as their constituent amino acids. Thus, apart from the difficulties of ensuring complete recovery of secretions, the rapid digestive and absorptive process invalidates the above techniques for quantification of normal and abnormal losses of serum proteins into the gut lumen. By the same reasoning nitrogen balance studies may fail to detect loss of proteins (Jarnum, 1963) unless the abnormal process involves the large intestine.

\section{Disorders Associated with Excessive Gastrointestinal Protein Loss}

The mechanism of protein loss is understood in only a minority of the associated disorders. In this category are two groups of disease processes. In the first group the process results in ulceration of an area of gastrointestinal mucosa with resultant exudation of plasma and interstitial fluid. This is probably the explanation in diffuse chronic gastritis, acute gastroenteritis, shigella dysentery, regional granulomatous enteritis, and ulcerative colitis. Secondary ulceration of neoplastic lesions may have a similar effect.

The second group is composed of diseases associated with obstruction to intestinal lymphatics. This may result in loss of protein-rich and lymphocyte-rich fluid into the intestinal lumen. Primary involvement occurs in intestinal lymphangiectasia, Whipple's disease, retroperitoneal fibrosis, and malignant lymphomas affecting the mesenteric lymphatics. Defects in lymph drainage via the main lymphatic channels may also occur secondary to a severe increase in central venous pressure. This may be the case in constrictive pericarditis, tricuspid incompetence, and thrombosis of the superior vena cava.

In the vast majority of gastrointestinal disorders associated with abnormal protein loss the pathophysiology is unknown. The main diseases in this category are giant gastric rugal hypertrophy, gluteninduced enteropathy, tropical sprue, allergic gastroenteropathy, intestinal parasitic infestation (such as giardiasis and hookworm), and diffuse colonic polyposis. In these disorders, the pathology may be distinctive and the segment of the gastrointestinal tract responsible for the abnormal loss may be localized. In other disorders the intestinal protein loss seems to be generalized; certain dysgammaglobulinaemias, the carcinoid syndrome, the nephrotic syndrome, amyloidosis, scleroderma, systemic lupus erythematosus, angioneurotic oedema, and post-cytotoxic therapy are but a few of the disorders in this category. A comprehensive list of all the recorded protein-losing enteropathies is provided by Schultze and Heremans (1966) and Waldmann (1970).

An interesting feature of the normal transport of proteins from plasma to gut lumen, which persists in all forms of protein-losing enteropathy, is the apparent lack of selectivity with regard to molecular size of the proteins leaking into the intestinal lumen. The fraction of the intravascular pool which leaks into the lumen in both health and disease seems to be the same for a variety of different sized proteins: albumin, transferrin, IgG, IgA, IgM, fibrinogen, caeruloplasmin, and lipoproteins (Waldmann, 1966). 
Thus, any selectivity of the capillary basement membrane appears to be absent and plasma proteins pass through in bulk in the same concentration as they exist in plasma. In contrast, endogenous fractional catabolic rates are widely different for these proteins, and although these rates also bear no systematic relationship to molecular size, they indicate the existence of a variety of mechanisms in addition to that of gut loss for the normal degradation of plasma proteins. A very different situation prevails in the nephrotic syndrome, where selectivity according to molecular size may be maintained. A similar investigative approach as that relating disordered function to ultrastructural changes in the glomerulus may prove equally valuable for the gastrointestinal mucosa.

\section{Detection and Measurement of Abnormal Gastro- intestinal Protein Loss}

The available techniques for the detection and quantification of plasma protein loss in the gut utilize a variety of radioisotopically labelled macromolecules. The ideal macromolecule would be albumin, since this is the predominant protein to be lost and contributes most to the reduction in total plasma protein levels. The ideal label would satisfy the following requirements.

CRITERIA FOR AN IDEAL LABEL

1 The labelling procedure or the presence of attached label should not alter the metabolic be- haviour of the protein. Its survival should be the same as that of unlabelled, native protein.

2 The label, once attached, should not be eluted from the protein, except as part of the normal degradation of the protein molecule.

3 There should be no loss of label into the gut lumen in any form, other than as the intact labelled protein. This includes isotope released by catabolism of the protein in sites other than the gastrointestinal tract. Failure to satisfy this condition would result in an overestimate of the gastrointestinal contribution to overall catabolism.

4 Once excreted into the gut lumen there should be no reabsorption of the isotope, either as intact labelled macromolecule or as free isotope released by digestive degradation of the macromolecule. Failure to satisfy this condition would result in an underestimate of protein loss in the gut.

5 Ideally, the isotope should be excreted minimally in the urine so as to reduce the risk of error due to urinary contamination of the stools.

6 Finally, the isotope should be freely available, reasonably priced and easily measured in the stools. The labelling procedure should be simple and there should be no radiation hazard to the patient.

A material complying with all these conditions $\vec{\theta}$ would permit calculation of enteric loss of protein bye expressing stool radioactivity as a percentage of plasma radioactivity, ie, a clearance as fractiona rate of loss of the intravascular pool per day. How: ever, it would be ideal if the overall fractional catabolic rate of the protein could also be deter-

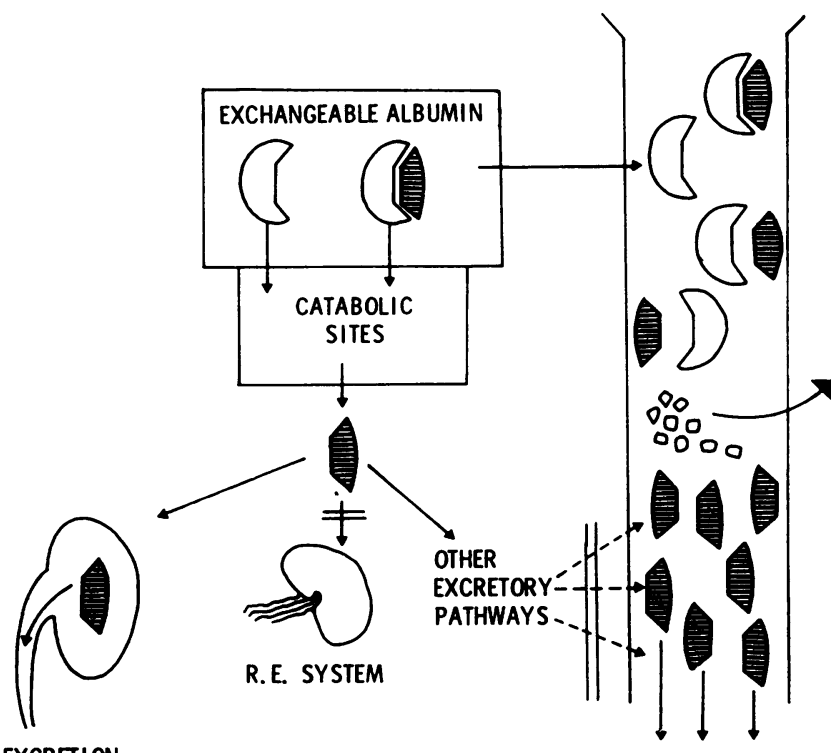

URINE EXCRETION
Fig. 1 Schematic diagram of the ideal properties of an isotopically labelled protein to be used for measurement of enteric protein loss and measurement of fractional catabolic rate. The macromolecule is indicated by the open symbol, the isotope by a shaded symbol. (This notation is used in all the Figures.) Albumin is used as an ideal protein. There is no discrimination between labelled and unlabelled albumin for catabolism or for passage into the gut. Isotope is released quantitatively into the urine following catabolism. There is no excessive uptake of labelled protein or free label by the reticuloendothelial system. There is no excretion of free label into the gut. Although there may be absorption of protein digestive products from the gut, released isotope should not be reabsorbed but should appear quantitatively in the faeces. 
mined. In the case of an isotope which is rapidly cleared by the kidney following its release from degraded protein, the overall fractional catabolic rate may be calculated as a percentage of the intravascular pool both from its rate of disappearance from the plasma and its rate of appearance in the urine. In order to be able to make both calculations with the same labelled macromolecule, condition 5 may have to be sacrificed (Fig. 1). Suffice it to say, that none of the labelled preparations available satisfy all these requirements. It may be of some value in this type of review to list these techniques and to evaluate their relative merits.

\section{TECHNIQUES}

\section{Radioiodinated plasma proteins (Fig. 2)}

Providing that care is taken with the preliminary protein fractionation procedure and with the degree and evenness of the iodination procedure (McFarlane, 1956 and 1958), ${ }^{131}$ I- or ${ }^{125}$ I-labelled proteins behave identically to native proteins (Campbell, Cuthbertson, Matthews, and McFarlane, 1956; Cohen, Holloway, Matthews, and McFarlane, 1956; Bennhold and Kallee, 1959). Radioactive iodine liberated by endogenous catabolism of intravascular protein is excreted in the urine providing that the thyroid gland is blocked with stable iodide. Evaluation of the semi-logarithmic plot of plasma radioactivity and excreted urine radioactivity gives a measure of the intravascular and total exchangeable pool, the fractional catabolic rate, and by inference in steady-state conditions the synthetic rate of the protein. The labelling procedure is simple and there is no risk to the patient. Thus, criteria 1,2 , and 6 (above) are satisfied. Unfortunately, radioactive iodide released by endogenous catabolism is not exclusively excreted by the kidneys; it appears in appreciable amounts as iodide actively secreted by the salivary, gastric, and small intestinal glands. In addition, both this iodide and ${ }^{131} \mathrm{I}$ or ${ }^{125} \mathrm{I}$ released from labelled protein which may have leaked into the intestinal lumen is rapidly reabsorbed further down the intestine and is predominantly excreted in the urine. The total effect of this recycling of iodide is to produce a low stool radioactivity and an underestimate of enteric protein loss (Kerr, Du Bois, and Holt, 1967). Attempts have been made to overcome these limitations to requirements 3 and 4 . Measurement of protein-bound activity by direct intubation of accessible parts of the gastrointestinal tract may give an indication of localized protein loss (Citrin $e t$ $a l, 1957)$. By design, such studies are short-term and may give a quantitative overestimate of daily losses by this route (Tavill, 1970). Attempts have been made to prevent reabsorption of released, luminal radioactive iodide by the administration of an anionexchange resin, Amberlite IRA 400 (Jeejeebhoy and Coghill, 1961). However, in addition to the fact that the resin is inefficient at trapping all the ${ }^{131}$ I liberated (Freeman and Gordon, 1964), it has been shown that all the radioactivity measured in the faeces could be accounted for by the salivary excretion of radioactive iodide (Jones and Morgan, 1963). Such

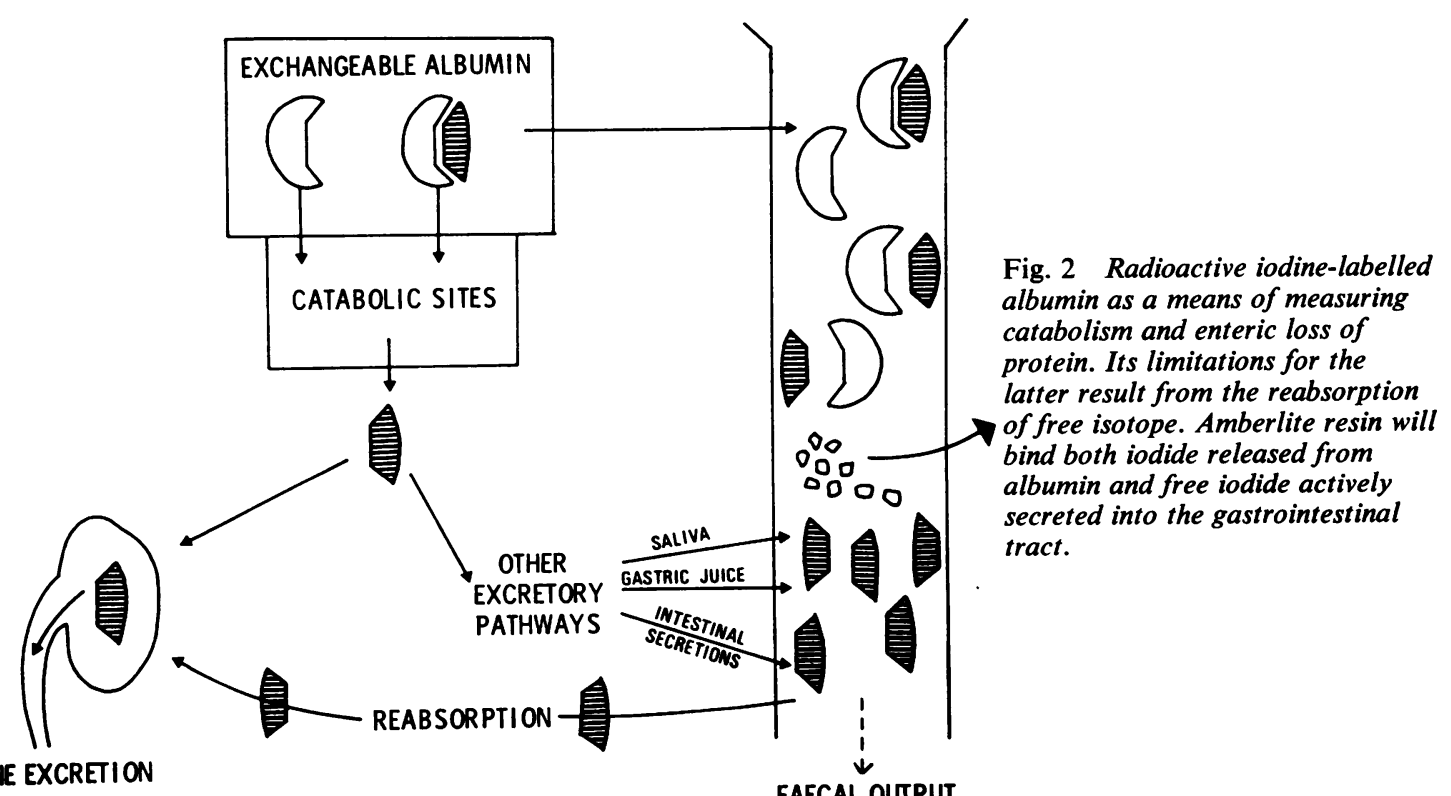

Fig. 2 Radioactive iodine-labelled albumin as a means of measuring catabolism and enteric loss of protein. Its limitations for the result from the reabsorption bind both iodide released from albumin and free iodide actively secreted into the gastrointestinal tract. 
observations invalidate radioactive iodine-labelled plasma proteins for direct quantification of enteric loss of protein. However, they remain the only reliable means for measurement of endogenous catabolism. In all the other techniques to be evaluated, correlation has been sought between gastrointestinal protein loss (exogenous catabolism) and endogenous catabolic rates measured with ${ }^{131}$ I- or ${ }^{125}$ I-labelled proteins. Such studies (Jarnum, 1963; Waldmann, 1966; Waldmann et al, 1969) have shown that gastrointestinal protein loss is associated with reduced body pool sizes, a shortened albumin survival, and with the steady state synthetic rates which were normal or slightly raised. Direct measurement of the albumin synthetic rate using the $\left({ }^{14} \mathrm{C}\right)$ carbonate technique in certain patients with gastrointestinal protein loss has demonstrated an increased rate of hepatic protein synthesis (Tavill, Craigie, and Rosenoer, 1968; Wochner, Weissmann, Waldmann, Houston, and Berlin, 1968).

Radioactive iodine-labelled protein studies are useful therefore only in distinguishing between hypercatabolism and diminished synthesis. They are of little value in detecting or quantifying loss of protein into the gastrointestinal tract.

\section{II ${ }^{131}$ I-labelled polyvinylpyrrolidine}

Gordon (1959) introduced ${ }^{131} \mathrm{I}$-polyvinylpyrrolidone as a substance to detect abnormal permeability to macromolecules in the digestive tract. It is a synthetic polymer with an average molecular weight of 40,000 which is unaffected by digestive enzymes and is only minimally absorbed from the gut lumen. Following intravenous injection normal subjects excrete $0-1.6 \%$ (mean $0.8 \%$ ) of the dose in the stools in four days. A similar range has been found by Dawson, Williams, and Williams (1961). In patients with gastrointestinal protein loss $2 \cdot 9-32.5 \%$ of the dose may appear in the stools in four days. Although there appears to be a clear-cut distinction between normals and abnormals, there are a number of serious limitations which preclude the use of ${ }^{131}$ Ipolyvinylpyrrolidone in the quantification of the protein loss. The preparation is unstable on standing. Between $6 \%$ and $56 \%$ of its radioactivity is dialyzable. An inverse correlation is found between the size of the dialyzable fraction and the magnitude of the faecal 131I output (Jarnum, 1963). In addition, variable amounts (between $10 \%$ and $68 \%$ ) of the ${ }^{131} \mathrm{I}$ label that enters the gastrointestinal tract are absorbed (Gordon, 1959; Jarnum, 1961). It is not a normal metabolite and consequently disappears rapidly from the plasma, being taken up in the reticuloendothelial system within 48 hours of injection. No significant correlation exists between the excreted activity and the plasma albumin concentra- tion or the fractional catabolic rate (Jarnum, Westergaard, Yssing, and Jensen, 1968). It thus provides no information about endogenous protein catabolism and no quantitative assessment of protein loss. Its place seems to be limited to that of a simple screening test.

\section{III ${ }^{51}$ CR-labelled proteins (Fig. 3)}

${ }^{51} \mathrm{Cr}$ )albumin was first introduced by Waldmann in 1961 as a means of quantifying gastrointestinal protein loss. More recently he and his coworkers have reviewed their accumulated experience with this compound (Waldmann et al, 1969). A total of 230 studies were carried out in 180 subjects: 50 controls with normal serum albumin levels and no evidence of gastrointestinal disease and 130 patients with hypoalbuminaemia which could not be explained by proteinuria or liver disease. Repeated ${ }^{51} \mathrm{Cr}$ studies were performed on 25 patients; and 70 patients had combined $\left({ }^{51} \mathrm{Cr}\right)$ albumin and $\left({ }^{125} \mathrm{I}\right)$ albumin studies.

Carrier-free ${ }^{51} \mathrm{CrCl}_{3}$ of high specific activity is incubated with albumin at $p \mathrm{H} 5.5$ for 30 minutes. Excess ${ }^{51} \mathrm{Cr}$ is removed on an Amberlite MB-1 resin column, previously washed with a relatively large volume of unlabelled albumin solution. The efficiency of labelling varies between 23 and $50 \%$, and $85-96 \%$ of the radioactivity of the final preparation is precipitable with phosphotungstic acid (PTA). Of the protein-bound activity, $95 \%$ migrates with albumin on electrophoresis and $2-3 \%$ as $\beta$-globulin. The $\left({ }^{51} \mathrm{Cr}\right)$ albumin $(10-30 \mu \mathrm{Ci})$ is administered intravenously. For screening purposes, the percentage of the administered dose appearing in the first four days' stool is measured. However, this does not take advantage of the relatively long survival of $\left({ }^{51} \mathrm{Cr}\right)$ albumin in the serum. A more meaningful expression of stool loss as a clearance in percentage of the plasma pool lost per day can be calculated from the third to 12th day of the study. To allow for intestinal transit time the stool loss should be related to the prevailing radioactivity in the preceding 24 hours.

Following oral administration of $\left({ }^{51} \mathrm{Cr}\right)$ albumin, $93-99 \%$ of the dose is recovered in the stools. Requirement 4 (above) is therefore satisfied. There would be no significant reabsorption of excreted ${ }^{51} \mathrm{Cr}$. The metabolic half-life in the plasma in normal subjects ranges from $3 \cdot 5$ to 11 days (mean 7 days). This is much shorter than that of a preparation of radioiodinated albumin administered simultaneously to normal controls (13-20 days). A preparation of albumin doubly labelled with ${ }^{125} \mathrm{I}$ and ${ }^{51} \mathrm{Cr}$ gave a $t \frac{1}{2}$ of 17 days for the former and five days for the latter isotope. This clearly indicates that the shortened survival of $\left({ }^{51} \mathrm{Cr}\right.$ )albumin is not due to denaturation of the protein but is rather due to elution of the label. This was also shown by Kerr et al 


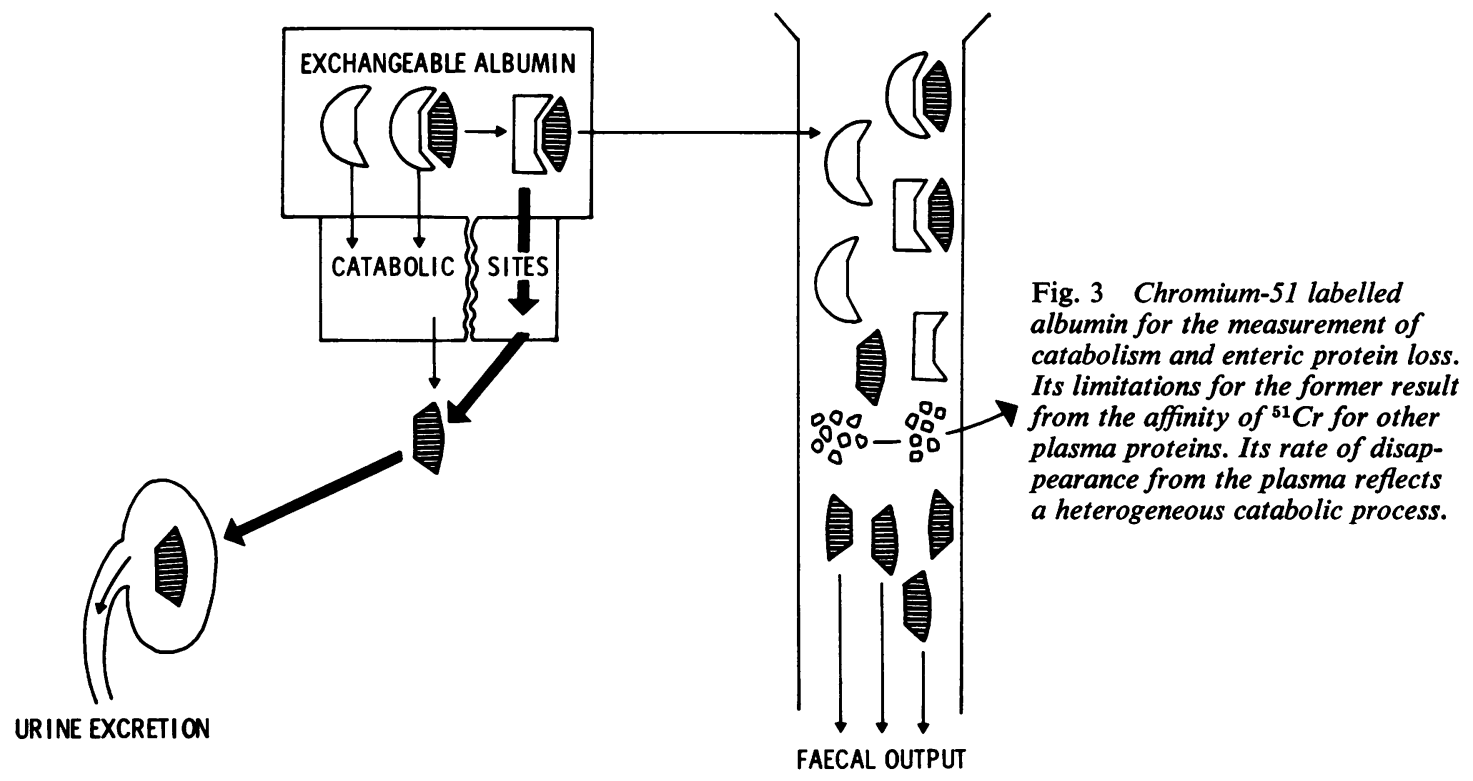

(1967) using ( $\left.{ }^{125} \mathrm{I}\right)$ albumin heavily labelled with ${ }^{51} \mathrm{Cr}$. Elution of the label is associated with labelling of $\beta$-globulins, in particular transferrin. In fact the $t \frac{1}{2}$ of the exponential part of the plasma curve after intravenous $\left({ }^{51} \mathrm{Cr}\right.$ )albumin approaches the mean $t_{\frac{1}{2}}$ of transferrin of 8.7 days (Jarnum and Lassen, 1961). The transfer of label from $\left({ }^{51} \mathrm{Cr}\right.$ )albumin to $\beta$-globulins can be minimized by the addition of ferric chloride to labelled serum in vitro (Van Tongeren and Majoor, 1966).

The shortened metabolic survival of $\left({ }^{51} \mathrm{Cr}\right)-$ albumin, although not the result of denaturation, precludes its use for measurement of rates of catabolism or synthesis. However, it remains valid to calculate protein loss or clearance into the gut since this makes the assumption only that the specific activity of the protein lost is the same as that of the plasma. Direct validation of this assumption has been provided by comparison of plasma albumin with albumin leaked into the pleural fluid of a patient with pleural effusion and into the urine of a patient with nephrotic syndrome. The specific radioactivities were similar in both instances. Likewise, the specific activity of both ${ }^{125} \mathrm{I}$ - and ${ }^{51} \mathrm{Cr}$-labelled albumin was closely similar in plasma, bile, and gastric juice of the experimental dog (Kerr et al, 1967).

Stool excretion in normal subjects varies between 0.1 and $0.7 \%$ of the injected dose in four days. Stool clearance of ${ }^{51} \mathrm{Cr}$ is $0.2-1.6 \%$ (mean $0.64 \%$ ) of the plasma pool per day, representing $2-15 \%$ (mean $6.4 \%$ ) of the overall catabolism of albumin (Wald- mann et al, 1969). Of the patients with hypoalbuminaemia, those with a normal ( $\left.{ }^{125} \mathrm{I}\right)$ albumin fractional catabolic rate excreted less than $0.7 \%$ of the dose in four days. Thus, no false negatives were detected. The remainder excreted $0.9-35 \%$ of the injected dose in four days. All those with an excretion in excess of $2 \%$ of the dose had a significantly raised fractional $\left({ }^{125} \mathrm{I}\right)$ albumin catabolic rate. Thus, no false positives were found. Clearances in 20 of these patients with abnormal excretions demonstrated a loss of $2-60 \%$ of the intravascular pool per day. In addition, in patients in whom appropriate therapy was employed there was complete return of an abnormal ${ }^{51} \mathrm{Cr}$ loss to the normal range.

The properties of $\left({ }^{51} \mathrm{Cr}\right)$ albumin may be summarized in relation to the criteria listed above for an ideal label.

1 The labelling procedure does not appear to alter the metabolic behaviour of the protein, but since its survival can be measured only by the persistence of label, elution produces effectively the same result.

2 Elution of label and reattachment to other plasma proteins, in particular transferrin, precludes its use in the determination of the endogenous catabolism of any individual protein.

3 In spite of multiple labelling, the ${ }^{51} \mathrm{Cr}$ excreted into the bowel is protein-bound. Since the ratio of concentrations of proteins in the plasma is similar to the ratio of proteins appearing in the gut lumen, it is still possible to express loss as a clearance or ratio between excreted label and total intravascular 
activity. Whether one makes the calculation from individual ratios of stool and plasma activity (Waldmann et al, 1969) or from total stool loss as a percentage of the integrated plasma radioactivity curve (Van Tongeren and Reichert, 1966) makes little difference. The clearance appears to remain constant after equilibration. The use of the clearance method enables determination of the fraction of overall breakdown that occurs by loss into the gut; it minimizes errors due to variation in stool transit time, and avoids errors due to variable distribution, degradation, and excretion by the kidneys.

4 There is no significant reabsorption of label excreted into the gut lumen. In this respect it is considerably superior to radioactive iodine.

5 As with $\left({ }^{131} \mathrm{I}\right)$ or $\left({ }^{125} \mathrm{I}\right)$ albumin, the appearance of ${ }^{51} \mathrm{Cr}$ in the urine during the post-equilibration period reflects endogenous degradation of labelled proteins. Precautions are necessary during the clearance study to avoid contamination of faeces with urine.

6 The isotope is easily counted in plasma and stools. Its peak energy permits discrimination from ${ }^{125} \mathrm{I}$ but not from ${ }^{131} \mathrm{I}$. Since ${ }^{51} \mathrm{Cr}$ is eluted from labelled albumin in vitro there is little point in undertaking any laboratory labelling procedure. Intravenously injected ${ }^{51} \mathrm{CrCl}_{3}$ will bind avidly to plasma proteins in vivo. The disappearance rate of ${ }^{51} \mathrm{Cr}$ from plasma following such an intravenous injection is identical with that of labelled albumin in vitro or whole serum (Van Tongeren and Majoor, 1966).

A close correlation between the clearance of ${ }^{51} \mathrm{Cr}$ and both serum albumin level and fractional catabolic rate has been found in those patients in whom hypoalbuminaemia is not associated with diminished synthesis (Waldmann et al, 1969). Thus, providing that endogenous catabolism is independently assessed with radioactive iodine-labelled serum albumin, the fraction of overall breakdown that results from loss into the gut can be assessed with ${ }^{51} \mathrm{Cr}$. This is because the same fractional rate of clearance exists for all the plasma proteins labelled in vivo. In this way it is possible to assess abnormal loss and also to provide some estimate of the gastrointestinal role in normal catabolism. Figures of around $10 \%$ of overall catabolism in normal subjects agree well with estimates made by other acceptable methods of investigation.

\section{IV ${ }^{95} \mathrm{NB}$-labelled albumin (Fig. 4)}

Albumin can be labelled electrolytically with ${ }^{95}$ niobium and the unreacted isotope removed by dialysis or by passage through DEAE-cellulose. Such a preparation has been used for the study of gastrointestinal protein loss (Jeejeebhoy, Singh, Mani, and Sanjana, 1965; Jeejeebhoy, Jarnum Singh, Nadkarni, and Westergaard, 1968) in 18 control patients and five patients with protein-losing enteropathy. Although some of the control patients had low serum albumin levels all had either a normai

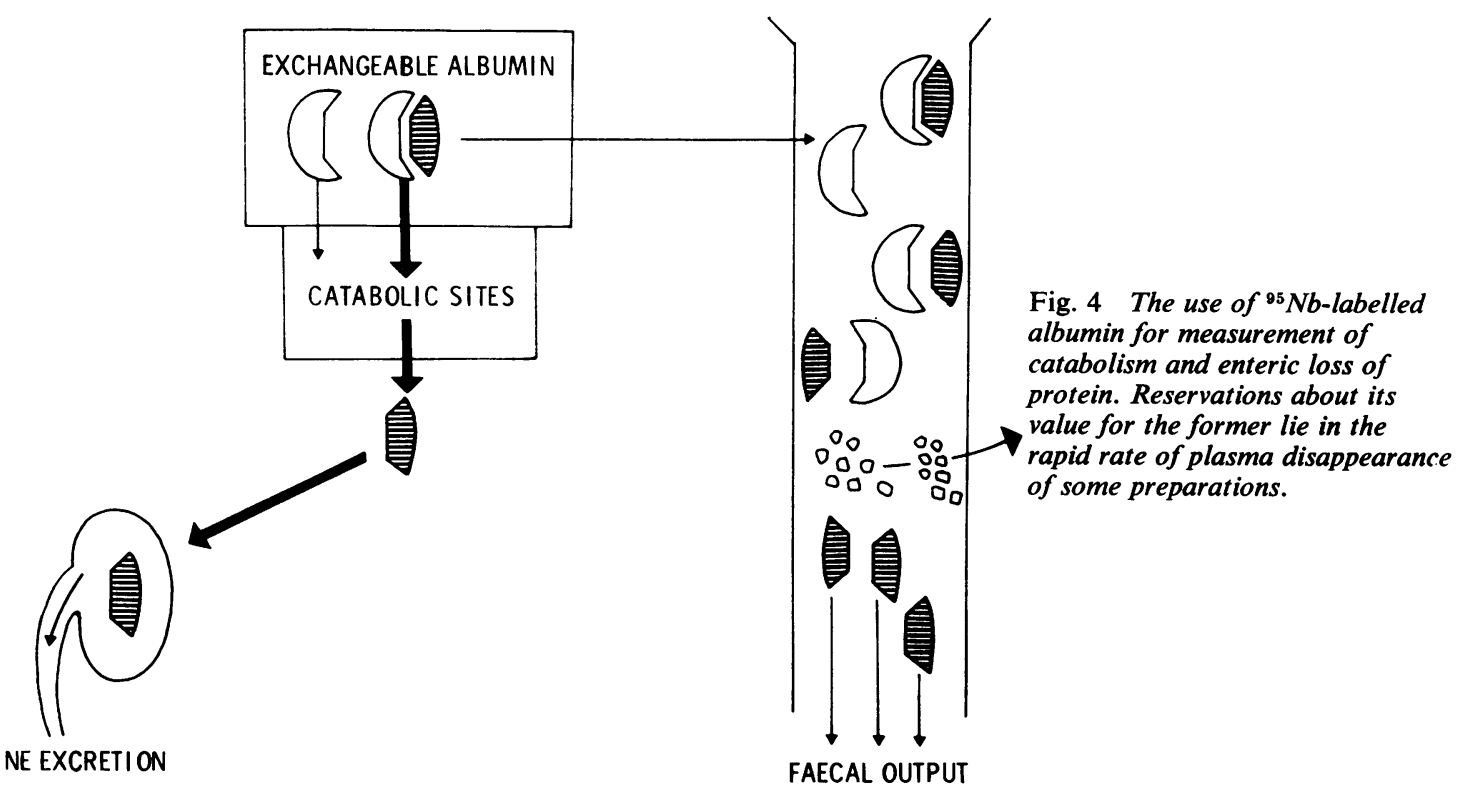


${ }^{51} \mathrm{Cr}$ )albumin test or a normal catabolic rate measured with ( $\left.{ }^{131} I\right)$ albumin. The five patients with protein-losing enteropathy had been judged abnormal on the basis of an elevated catabolic rate and an abnormal ${ }^{51} \mathrm{Fe}$ iron dextran or ${ }^{51} \mathrm{Cr}$-labelled albumin test.

Studies in vitro on the $\left({ }^{95} \mathrm{Nb}\right)$ albumin preparation show that $77-85 \%$ is non-dialysable and $54-72 \%$ is precipitable with trichloracetic acid, while only $7-31 \%$ is non-dialysable against a protein-containing solution. The latter may be improved by second treatment on a DEAE-cellulose column. This results in a preparation which on electrophoresis or DEAESephadex A50 chromatography shows radioactivity exclusively confined to the albumin peak.

Criteria of acceptability are based on the comparative behaviour of $\left({ }^{95} \mathrm{Nb}\right)$ albumin and $\left({ }^{131} \mathrm{I}\right)$ albumin in vivo. Comparison of plasma disappearance curves expressed as ratios of fractional catabolic rates calculated by graphical analysis (Matthews, 1957) show good agreement between the two preparations. In controls, for the first six days, ${ }^{95} \mathrm{Nb}$ ranges from $0.1-7.0 \%$ (mean $2.0 \%$ ) of the injected dose while the faecal clearance expressed as a percentage of the intravascular $\left({ }^{95} \mathrm{Nb}\right.$ )albumin pool is $0 \cdot 3-2 \cdot 2 \%$ (mean 1.2\%) per day. In patients with proven enteric protein loss the faecal excretion of ${ }^{95} \mathrm{Nb}$ increases to $7-31 \%$ of the injected dose in six days, giving a clearance of $3-33 \%$ of the intravascular pool per day.

In all groups of patients the urinary excretion is low compared to that of ${ }^{131} \mathrm{I}$ or ${ }^{125} \mathrm{I}$ in studies using radioactive iodine albumin. The urinary clearance cannot therefore be used to calculate endogenous catabolic rates. However, it is still possible to estimate faecal clearance as a percentage of the overall catabolic rate. A value of about $12 \%$ of the total compares well with figures obtained using other techniques.

Providing that care is taken in the labelling process to remove excess ${ }^{95} \mathrm{Nb}$ and to purify further the protein by DEAE chromatography, a labelled protein can be prepared which has a similar metabolic behaviour to ( $\left.{ }^{131} \mathrm{I}\right)$ albumin. There is no evidence that non-protein-bound ${ }^{95} \mathrm{Nb}$ normally passes into the gastrointestinal lumen, and no evidence for significant reabsorption. The dialysability of the preparation does not seem to alter over a period of 10 days and does not appear to affect the faecal excretion of ${ }^{95} \mathrm{Nb}$ providing this is expressed as a clearance of the intravascular $\left({ }^{95} \mathrm{Nb}\right)$ albumin pool. Urine contamination of faeces may be a source of experimental error. The isotope has the advantage of reasonably long physical half-life and its peak energy makes it easy to discriminate from the other isotopes in common use for this purpose.

$V^{59} \mathrm{Fe}$-labelled iron dextran (Fig. 5)

Andersen and Jarnum (1966) introduced ${ }^{59} \mathrm{Fe}-$ labelled iron dextran as a means of overcoming the errors due to urine contamination of faeces which are present with the ${ }^{51} \mathrm{Cr}$ method. No radioactivity

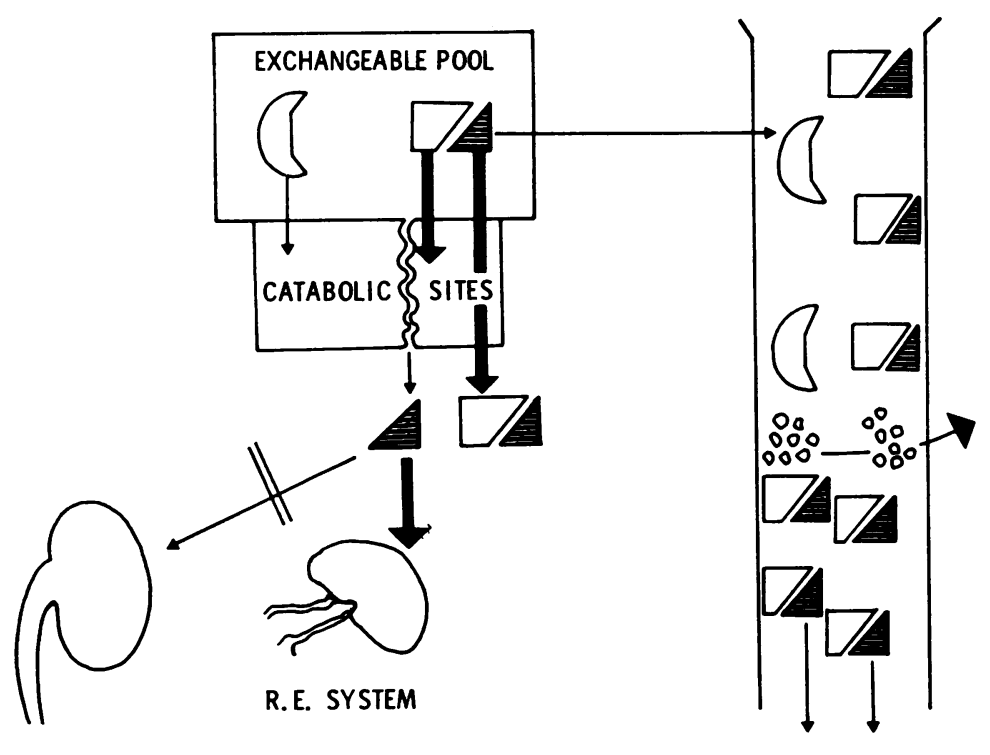

Fig. 5 The use of ${ }^{59} \mathrm{Fe}$-iron dextran for quantification of enteric protein loss. Not being a protein, its rate of disappearance from the plasma is very rapid owing to uptake by the reticuloendothelial system. However, urine loss of isotope does not occur and faecal output of isotope can be expressed as a clearance from the plasma during a short-term study. 
appears in the urine following intravenous injection of this preparation. Although these earlier studies indicate a variable recovery of an orally administered dose of $\left({ }^{50} \mathrm{Fe}\right)$ iron dextran in the faeces $(51-105 \%)$, there is clear separation of the faecal loss of an intravenously injected preparation in normals and patients with enteric protein loss $(0 \cdot 2-0 \cdot 7 \%$ against $1 \cdot 0-13 \cdot 8 \%$ ). Stools are collected from the time of injection until the appearance of a carmine marker swallowed four days after the injection.

Iron dextran has a molecular weight spectrum between 50,000 and 250,000 and it is speculated that its faecal clearance might be related to the enteric loss of plasma proteins with a similar molecular weight range. Its plasma disappearance rate on the other hand is very different to that of any plasma protein. It disappears from the plasma with a t $\frac{1}{2}$ of 16-21 hours. Nevertheless, its plasma clearance into the faeces is 0 to $0.8 \%$ (mean $0.4 \%$ ) of the plasma pool per day which compares well with that of ${ }^{51} \mathrm{Cr}$ administered as ${ }^{51} \mathrm{CrCl}_{3}$ (Jarnum et al, 1968). It is possible to discriminate ${ }^{59} \mathrm{Fe}$ in the presence of ${ }^{131} \mathrm{I}$, ${ }^{125} \mathrm{I}$, or ${ }^{51} \mathrm{Cr}$; this is a distinct advantage over the latter isotope which can be measured in the presence of ${ }^{125}$ I only. In a definitive study in 21 patients with protein-losing gastroenteropathy, Jarnum et al (1968) demonstrated a clearance of $\left({ }^{59} \mathrm{Fe}\right)$ iron dextran ranging between 2.0 and $32.6 \%$ (mean $11.3 \%$ ) of the intravascular pool per day. There is a significant negative correlation between serum albumin and faecal ${ }^{59} \mathrm{Fe}$ clearance and a significant positive correlation between fractional catabolic rate and faecal
${ }^{59} \mathrm{Fe}$ clearance. This is in spite of the fact that in three patients who received simultaneous ${ }^{59} \mathrm{Fe}$ labelled iron dextran and ${ }^{51} \mathrm{CrCl}_{3}$ the clearance of ${ }^{59} \mathrm{Fe}$ was less than that of ${ }^{51} \mathrm{Cr}$ in every case. In fact, from the regression coefficient relating faecal ${ }^{59} \mathrm{Fe}$ clearance to fractional catabolic rate it is calculated that a four-fold increase in the latter would be reflected by only a two-fold increase in clearance. Thus, although the evidence points to bulk loss of macromolecules through the intestinal mucosa there may be some retention of leaked-out ${ }^{59} \mathrm{Fe}$ or possibly even some reabsorption through diseased areas.

Since iron dextran is a synthetic polymer and not a protein it can give no information about overall protein catabolism. However, although it is rapidly taken up by the reticuloendothelial system, its rate of clearance into the gut is useful in the detection of increased enteric protein loss. Its special advantages lie in the ease of counting in the presence of other isotopes, its absence in the urine, and the fact that only a short-term study is necessary.

\section{$V I{ }^{6}{ }^{7} \mathrm{Cu}$-labelled caeruloplasmin (Fig. 6)}

It has been pointed out by Waldmann, Morell, Wochner, Strober, and Sternlieb (1967) that caeruloplasmin labelled with ${ }^{67} \mathrm{Cu}$ possesses many of the qualities of the ideal label for the detection of gastros intestinal protein loss. It is a plasma protein (mole cular weight 140,000 ) containing eight copper atoms as an intrinsic part of the molecule. Although the copper atoms can be exchanged in vitro this does not occur in vivo. Introduction of ${ }^{67} \mathrm{Cu}$ into the molecule

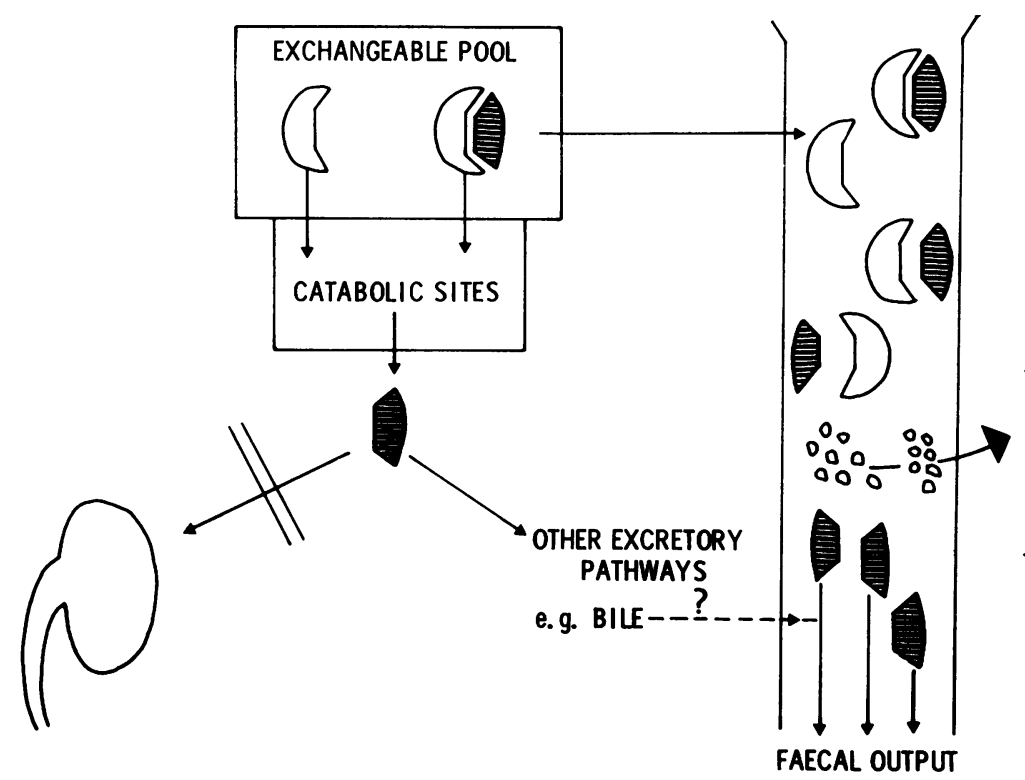

Fig. 6 The use of ${ }^{67} \mathrm{Cu}$-labelled caeruloplasmin for measurement of catabolism and enteric loss of protein. Although urine excretion is minimal, its rate of disappearance from the plasma gives a measure of catabolic rate. Providing that some correction for biliary excretion of ${ }^{67} \mathrm{Cu}$ is made, the faecal output of isotope reflects the clearance of labelled caeruloplasmin from the plasma into the gut lumen. 
in vitro does not alter the metabolic behaviour of the protein (Sternlieb, Morell, Tucker, Greene, and Scheinberg, 1961). Radioactive non-protein bound copper is not actively secreted into gut lumen and is relatively poorly absorbed. Urine loss is minimal. It can therefore be used for estimation of overall catabolism (and in the steady state also synthesis) and for the measurement of the role of the gastrointestinal tract in normal and abnormal metabolism.

Preparation and labelling of a pure caeruloplasmin is an arduous task. The final preparation gives a single line on Ouchterlony immunodiffusion against anti-whole human serum, and over $98 \%$ of the ${ }^{67} \mathrm{Cu}$ is precipitable with phosphotungstic acid.

The plasma $t \frac{1}{2}$ averages $6 \cdot 1$ days and the fractional catabolic rate of $17.8 \%$ of the intravascular pool per day compares well with a figure of $21 \%$ for ${ }^{125} \mathrm{I}$ labelled caeruloplasmin. Clearance into the stool, expressed as the ratio of counts in the stool per 24 hours to counts in the intravascular pool 24 hours earlier, ranges from 1.9 to $3.9 \%$ of the intravascular pool per day. This accounts for only $11-22 \%$ of the normal total catabolism. The use of multicompartmental analysis corrects for loss of some unbound ${ }^{67} \mathrm{Cu}$ into the bowel released from catabolized caeruloplasmin and brings this figure down to less than $10 \%$ of overall catabolism.

In patients with lymphangiectasia and protein loss the plasma $t_{\frac{1}{2}}$ may be reduced to $3 \cdot 1$ days, giving a fractional catabolic rate of $32.4 \%$ of the intravascular pool per day. The gastrointestinal clearance of ${ }^{67} \mathrm{Cu}$ under these circumstances is increased to $25.5 \%$ of the intravascular pool per day, accounting for $75 \%$ of total catabolism. Thus, there is good correlation between fractional catabolic rate and stool loss.

It is clear that $\left({ }^{67} \mathrm{Cu}\right)$ caeruloplasmin studies can give precise quantification of both enteric loss and overall catabolism. However, the preparation is difficult and expensive to produce and the isotope has an inconveniently short half-life of 62 hours. On the other hand, it has given a very accurate indication of the role of the gastrointestinal tract in normal catabolism and may be of special value in pathological states where other techniques give contradictory results.

\section{Summary}

The suspicion of protein-losing enteropathy should be aroused in any hypoproteinaemic situation in which no obvious cause for diminished protein synthesis or excessive loss by other routes is evident. It is necessary to exclude liver disease, protein malnutrition, and the nephrotic syndrome in the first instance. The most difficult situation may arise in steatorrhoeic states, many of which can be associated with excessive protein loss in addition to diminished synthesis consequent upon impaired digestion or absorption. Such conditions may be diagnosed by means of specific tests of absorption, histological examination of mucosal biopsies, intestinal bacteriology and parasitology, pancreatic function tests, and a variety of radiological techniques, including barium studies and lymphangiography.

The situation may still remain where it is impossible to distinguish between diminished synthesis and excessive degradation. This requires investigation with radioactive iodine-labelled albumin. If this shows a diminished survival of labelled protein, then excessive degradation is the explanation for the hypoproteinaemia. However, it gives no clue as to the cause of hypercatabolism and other specific tests for enteric protein loss are required. The advantages and disadvantages of the available techniques are summarized in Table I. It seems that for routine use intravenous ${ }^{51} \mathrm{CrCl}_{3}$ is the best available technique, and that stool clearance should be expressed as a ratio of faecal to total plasma rarioactivity.

\begin{tabular}{|c|c|c|c|c|c|}
\hline \multicolumn{2}{|c|}{ Technique } & \multirow{2}{*}{$\begin{array}{l}\text { Measurement of Pool } \\
\text { Sizes and Endogenous } \\
\text { Catabolism } \\
\text { Yes }\end{array}$} & \multirow{2}{*}{$\begin{array}{l}\text { Quantification of } \\
\text { Enteric Loss as } \\
\text { Fraction of Intra- } \\
\text { vascular Pool cleared } \\
\text { per Day } \\
\text { No }\end{array}$} & \multirow{2}{*}{$\begin{array}{l}\text { Urine Excretion } \\
\text { of Isotope } \\
\text { Yes }\end{array}$} & \multirow{2}{*}{$\begin{array}{l}\text { Comment } \\
\begin{array}{l}\text { For detection of hypercatabol- } \\
\text { ism; to be used in conjunction } \\
\text { with other tests }\end{array}\end{array}$} \\
\hline I & Radioactive iodine labelled proteins & & & & \\
\hline $\begin{array}{r}\text { II } \\
\text { III }\end{array}$ & $\begin{array}{l}\left({ }^{131} \mathrm{I}\right) \text { polyvinylpyrrolidone } \\
\left({ }^{51} \mathrm{Cr}\right) \text { albumin }\end{array}$ & $\begin{array}{l}\text { No } \\
\text { No }\end{array}$ & $\begin{array}{l}\text { No } \\
\text { Yes }\end{array}$ & $\begin{array}{l}\text { Yes } \\
\text { Yes }\end{array}$ & $\begin{array}{l}\text { Can be used as a screening test } \\
\text { Valuable. Can be simplified by } \\
\text { using in vivo labelling with } \mathrm{CrCl}_{3}\end{array}$ \\
\hline IV & $\left({ }^{95} \mathrm{Nb}\right)$ albumin & Possible, with care & Yes & Yes & $\begin{array}{l}\text { May prove valuable for routine } \\
\text { use }\end{array}$ \\
\hline $\mathbf{V}$ & $\left({ }^{9} \mathrm{Fe}\right)$ iron dextran & No & No & No & $\begin{array}{l}\text { Can be used as a rapid screening } \\
\text { test. Easy to discriminate from } \\
\text { isotopes }\end{array}$ \\
\hline VI & $\left({ }^{67} \mathrm{Cu}\right)$ caeruloplasmin & Yes & Yes & Minimal & Too costly for routine use \\
\hline
\end{tabular}

Table I An assessment of the relative merits of the available methods for measuring enteric loss of plasma protein 
References

Andersen, S. B., and Jarnum, S. (1965). Gastrointestinal protein loss measured with ${ }^{59} \mathrm{Fe}$-labelled iron-dextran. Lancet, 1, 10601062.

Barandun, S., Aebersold, J., Bianchi, R., Kluthe, R., Muralt, G., Poretti, G., and Riva, G. (1960). Protein diarrhoea. With a contribution to the problem of so-called essential hypoproteinaemia. Schweiz. med. Wschr., 90, 1458-1467.

Bennhold, H., and Kallee, E. (1959). Comparative studies on the halflife of ${ }^{131} \mathrm{I}$-labelled albumins and non-radioactive human serum albumin in a case of analbuminaemia. J. clin. Invest., 38, 863-872.

Campbell, R. M., Cuthbertson, D. P., Matthews, C. M., and McFarlane, A. S. (1956). Behaviour of ${ }^{14} \mathrm{C}$ - and ${ }^{131} \mathrm{I}$-labelled plasma proteins in the rat. Int. J. appl. Radiat., 1, 66-84.

Citrin, Y., Sterling, K., and Halsted, J. A. (1957). The mechanism of hypoproteinaemia associated with giant hypertrophy of the gastric mucosa. New Engl. J. Med., 257, 906-912.

Cohen, S., Holloway, R. C., Matthews, C., and McFarlane, A. S. (1956). Distribution and elimination of ${ }^{131} \mathrm{I}-$ and ${ }^{14} \mathrm{C}$-labelled plasma proteins in the rabbit. Biochem. J., 62, 143-154.

Dawson, A. M., Williams, R., and Williams, H. S. (1961). Faecal P.V.P. excretion in hypoalbuminaemia and gastrointestinal disease. Brit. med. J., 2, 667-670.

Freeman, T., and Gordon, A. H. (1964). The measurement of albumin leak into the gastrointestinal tract using ${ }^{131}$ I-albumin and ion exchange resin by mouth. Gut, 5, 155-157.

Gordon, R. S. (1959). Exudative enteropathy: abnormal permeability of the gastrointestinal tract demonstrable with labelled polyvinylpyrrolidone. Lancet, 1, 325-326.

Gullberg, R., and Olhagen, B. (1959). Electrophoresis of human gastric juice. Nature (Lond.), 184, 1848-1849.

Holman, H., Nickel, W. F., and Sleisenger, M. H. (1959). Hypoproteinaemia antedating intestinal lesions, and possibly due to excessive serum protein loss into the intestine. Amer. J. Med., 27, 963-975.

Jarnum, S. (1961). The ${ }^{131} \mathrm{I}$-polyvinylpyrrolidone (131 I-PVP) test in gastrointestinal protein loss. Scand. J. clin. Lab. Invest., 13, 447-461.

Jarnum, S. (1963). In Protein-losing Gastroenteropathy. Blackwell, Oxford.

Jarnum, S., and Lassen, N. A. (1961). Albumin and transferrin metabolism in infectious and toxic diseases. Scand. J. clin. Lab. Invest., 13, 357-368.

Jarnum, S., Westergaard, H., Yssing, M., and Jensen, H. (1968). Quantitation of gastrointestinal protein loss by means of $\mathrm{Fe}^{59}$-labeled iron dextran. Gastroenterology, 55, 229-241

Jeejeebhoy, K. N., and Coghill, N. F. (1961). The measurement of gastrointestinal protein loss by a new method. Gut, 2, 123-130.

Jeejeebhoy, K. N., Jarnum, S., Singh, B., Nadkarni, G. D., and Westergaard, H. (1968). ${ }^{95} \mathrm{Nb}$-labelled albumin for the study of gastrointestinal albumin loss. Scand. J. Gastroent., 3, 449-457.

Jeejeebhoy, K. N., Singh, B., Mani, R. S., and Sanjana, S. M. (1965). The use of $\mathrm{Nb}^{95}$-labelled albumin in the study of gastrointestinal protein loss. In Physiology and Pathophysiology of Plasma Protein Metabolism, pp. 61-67. Proceedings of the third symposium, September 1964. Huber, Berne.

Jeffries, G. H., Holman, H. R., and Sleisenger, M. H. (1962). Plasma proteins and the gastrointestinal tract. New Engl. J. Med., 266, $652-660$.

Jones, J. H., and Morgan, D. B. (1963). Measurement of plasmaprotein loss into gastrointestinal tract using ${ }^{131}$ I-labelled proteins and oral Amberlite resin. Lancet, 1, 626-629.

Kerr, R. M., DuBois, J. J., and Holt, P. R. (1967). Use of ${ }^{125} \mathrm{I}$ - and ${ }^{51} \mathrm{Cr}$-labeled albumin for the measurement of gastrointestinal and total albumin catabolism. J. clin. Invest., 46, 2064-2082.

McFarlane, A. S. (1956). Labelling of plasma proteins with radioactive iodine. Biochem.J., 62, 135-143.

McFarlane, A. S. (1958). Efficient trace labelling of proteins with iodine. Nature (Lond.), 182, 53.

Matthews, C. M. E. (1957). The theory of tracer experiments with ${ }^{131} \mathrm{I}$-labelled plasma proteins. Phys. in Med. Biol., 2, 36-53.

Schultze, H. E., and Heremans, J. F. (1966). In Molecular Biology of Plasma Proteins, Vol. I, Nature and metabolism of extracellular proteins. Elsevier, Amsterdam.

Schwartz, M., and Thomsen, B. (1957). Idiopathic or hypercatabolic hyperproteinaemia: a case examined by ${ }^{131}$ I-labelled albumin. Brit. med. J., 1, 14-17.

Sternlieb, I., Morell, A. G., Tucker, W. D., Greene, M. W., and Scheinberg, I. H. (1961). The incorporation of copper into is ceruloplasmin in vivo: Studies with copper $^{64}$ and copper ${ }^{67}$. J. clin. Invest., 40, 1834-1840.

Tavill, A. S. (1970). In The Measurement of Hepatic Synthesis of Albumin in vivo. MD thesis, Manchester.

Tavill, A. S., Craigie, A., and Rosenoer, V. M. (1968). The measurement of the synthetic rate of albumin in man. Clin. Sci., 34, $1-28$.

Van Tongeren, J. H. M., and Majoor, C. L. H. (1966). Demonstration of protein-losing gastroenteropathy. The disappearance rate of ${ }^{51} \mathrm{Cr}$ from plasma and the binding of ${ }^{51} \mathrm{Cr}$ to different serum proteins. Clin. chim. Acta, 14, 31-41.

Van Tongeren, J. H. M., and Reichert, W. J. (1966). Demonstration of protein losing gastroenteropathy. The quantitative estimation of gastrointestinal protein loss, using ${ }^{51} \mathrm{Cr}$-labelled plasma proteins. Clin. chim. Acta, 14, 42-48.

Waldmann, T. A. (1961). Gastrointestinal protein loss demonstrate by ${ }^{51} \mathrm{Cr}$-labelled albumin. Lancet, 2, 121-123.

Waldmann, T. A. (1966). Protein-losing enteropathy. Gastroenterolog $50,422-443$.

Waldmann, T. A. (1970). Protein-losing enteropathy. In Moder Trends in Gastroenterology, edited by W. I. Card and B Creamer, pp. 125-142. Butterworth, London.

Waldmann, T. A., Morell, A. G., Wochner, R. D., Strober, W., and Sternlieb, I. (1967). Measurement of gastrointestinal protein loss using ceruloplasmin labeled with ${ }^{67}$ copper. $J$. clin. Invest. 46, $10-20$.

Waldmann, T. A., Wochner, R. D., and Strober, W. (1969). The role of the gastrointestinal tract in plasma protein metabolism. Studies with ${ }^{51} \mathrm{Cr}$-albumin. Amer. J. Med., 46, 275-285.

Wetterfors, J. (1965). Albumin. Investigations into the metabolism, distribution, and transfer of albumin under normal and certain pathological conditions, with special reference to the gastrointestinal tract. A clinical and experimental study. Acta med. scand. Suppl. 430.

Wochner, R. D., Weissmann, S. M., Waldmann, T. A., Houston, D., and Berlin, N. I. (1968). Direct measurement of the rates of synthesis of plasma proteins in control subjects and patients with gastrointestinal protein loss. J. clin. Invest., 47, 971-982. 